JSAP: Journal Syariah and Accounting Public

ISSN: 2622-3538

Available Online at https://journal.umgo.ac.id/index.php/JSAP/index

Vol. 4, No. 1 Juli 2021

DOI: $10.31314 /$ jsap.4.1.9-15.2021

\title{
PENGARUH RASIO KEMANDIRIAN, RASIO EFEKTIVITAS, DAN RASIO EFISIENSI TERHADAP PENDAPATAN ASLI DAERAH KABUPATEN GORONTALO
}

\author{
Nurul Farha M. Buka ${ }^{1}$, Yustina Hiola ${ }^{2}$ \\ 1,2, Program Studi Akuntansi Fakultas Ilmu Sosial Universitas Muhammadiyah Gorontalo \\ Email; nurulfarhambuka@gmail.com, yustinahiola@umgo.ac.id
}

Info Artikel: Diterima: 13 Nov. 2019, Disetujui: 17 Februari 2020, Publish 15 Juli 2021

\begin{abstract}
:
The research was conducted at department of regional financial and assets of Gorontalo Regency. The objective was to determine the influence of dependent variable there are independency, effectiveness, and efficiency ratio to the dependent variable, namely Original local government revenue (PAD). The method used multiple linear regressions. The results was the independence ratio, effectiveness ratio, and efficiency ratio together have a positive and significant effect, while partially the independence and effectiveness ratio have an effect on Original local government revenue where if the independence ratio and effectiveness ratio have increased, the original regional income will increase. Also, while the efficiency ratio has a negative and significant effect because when the efficiency ratio increases, local revenue will decrease.
\end{abstract}

Keywords: Independence Ratio, Effectiveness, Efficiency, PAD

\section{Abstrak:}

Penelitian ini dilakukan di Badan Keuangan dan Aset Daerah Kabupaten Gorontalo. Adapun tujuan penelitian ini adalah untuk melihat pengaruh variabel dependen yaitu rasio kemandirian, rasio efektivitas, dan rasio efisiensi terhadap variabel dependen yaitu Pendapatan Asli Daerah (PAD). Penelitian ini menggunakan metode regresi linear berganda. Hasil penelitian ini adalah rasio kemandirian, rasio efektivitas, dan rasio efisien secara bersama-sama berpengaruh positif dan signinifikan sedangan secara parsial rasio kemandirian dan rasio efektivitas berpengaruh terhadap pendapatan asli daerah dimana jika rasio kemandirian dan rasio efektivitas mengalami peningkatan maka pendapatan asli daerah akan mengalami peningkatan pula sedangkan untuk rasio efisiensi berpengaruh negatif dan signifikan karena ketika rasio efisiensi mengalami peningkatan maka pendapatan asli daerah akan mengalami penurunan.

Kata kunci : Rasio Kemandirian, Efektivitas, Efisiensi, PAD

\section{PENDAHULUAN}

Peran aktif dari pemerintah daerah dalam mengelola daerah sendiri merupakan tantangan yang harus diterima oleh pemerintah agar dapat membangun dan mengelola daerah masing-masing dengan baik. Sesuai dengan UU No. 23 Tahun 2014 tentang pemerintah daerah menjelaskan otonomi daerah adalah hak, wewenang, dan kewajiban daerah otonom untuk mengatur sendiri urusan pemerintahan dan kepentingan masyarakat setempat dalam 
sistem Negara Kesatuan Republik Indonesia.

Otonomi yang diberikan kepada kabupaten dan kota dilaksanakan dengan memberikan kewenangan yang kuat, nyata dan bertanggung jawab kepada pemerintah daerah secara proporsional. Otonomi daerah merupakan sebuah sistem yang memberikan keluasan kepada pemerintah daerah dalam mengelola dan mengurus semua sumber daya yang berada di daerah sendiri. Dengan adanya otonomi daerah setiap daerah memiliki kebebasan dalam menjalankan dan menyusun setiap agenda yang akan dijalankan di daerah tersebut. Dalam menjalankan otonomi daerah, pemerintah daerah dituntut untuk menjalankan roda pemerintahan yang efektif dan efisien, sehingga mampu mendorong masyarakat untuk berperan serta dalam melaksanakan pembangunan. Pemerintah daerah juga dituntut untuk meningkatkan pemerataan dan keadilan, sehingga dapat mengembangkan seluruh potensi yang dimiliki oleh masing-masing daerah. Keberhasilan otonomi daerah tidak terlepas dari pengelolaan keuangannya yang secara tertib, efisien, ekonomis, efektif, transparan, bertanggung jawab, serta harus sesuai dengan peraturan perundang- undangan yang berlaku.

Dalam rangka pelaksanaan kewenangan pemerintah daerah sebagaimana ditetapkan dalam UndangUndang Nomor 23 Tahun 2014 tentang pemerintah daerah, yang diikuti dengan perimbangan keuangan antara pemerintah pusat dan pemerintah daerah dengan diatur dalam Undang-Undang Nomor 33 Tahun 2004 tentang perimbangan keuangan antara pemerintah pusat dan pemerintah daerah timbul hak daerah yang dapat dinilai dengan uang sehingga perlu dikelola dalam suatu sistem pengelolaan keuangan daerah dan dikeluarkan Peraturan Pemerintah Republik Indonesia Nomor 58 Tahun 2005 tentang pengelolaan keuangan daerah. Untuk pengelolaan keuangan daerah dibutuhkan sumber daya ekonomi berupa keuangan yang dituangkan dalam suatu anggaran. Usaha pemerintah daerah dalam menggali sumber dana yang berasal dari potensi daerah serta kemampuan mengelola dan memanfaatkan sumber dana tercermin dalam Anggaran Pendapatan dan Belanja Daerah (APBD).

Kabupaten Gorontalo sebagai salah satu kabupaten yang berada di Provinsi Gorontalo memiliki banyak potensi yang dapat digali untuk dijadikan sumber pendapatan daerah. Perekonomian Kabupaten Gorontalo digerakan oleh beberapa industri seperti pangan, kimia dan bahan bangunan, kerajinan, sandang, logam dan elektronika yang dapat meningkatkan Pendapatan Asli Daerah (PAD). Namun pada kenyataannya sumber penerimaan/pendapatan terbesar Kabupaten Gorontalo adalah dana perimbangan dari Pemerintah Pusat dan untuk PAD masih terbilang sangat kecil.

Tabel 1. PAD Kab. Gorontalo

\begin{tabular}{|c|c|}
\hline Tahun & PAD \\
\hline 2014 & $105.365 .567 .589,29$ \\
\hline 2015 & $113.221 .503 .035,67$ \\
\hline 2016 & $125.271 .076 .533,68$ \\
\hline 2017 & $190.428 .308 .121,81$ \\
\hline 2018 & $147.992 .401 .409,49$ \\
\hline
\end{tabular}

Sumber : BKAD Kab. Gorontalo

Data di atas menunjukkan pendapatan Kabupaten Gorontalo masih didominasi oleh pendapatan yang bersumber dari pendapatan transfer, sedangkan Pendapatan Asli Daerah (PAD) relatif masih 
sangat kecil walaupun dari tahun 2014-2018 mengalami peningkatan namun pendapatan Kabupaten Gorontalo masih didominasi oleh pendapatan transfer dari pemerintah pusat.

PAD adalah penerimaan yang diperoleh daerah dari sumber-sumber dalam wilayahnya sendiri yang dipungut berdasarkan peraturan daerah yang sesuai dalam peraturan perundang-undangan yang berlaku. Menurut Abdul Halim (2004:94), Pendapatan Asli Daerah (PAD) adalah penerimaan yang diperoleh daerah dari sumber-sumber dalam wilayahnya sendiri yang dipungut berdasarkan peraturan daerah sesuai dengan peraturan perundangundangan yang berlaku.

Tujuan penelitian ini adalah untuk mengetahui pengaruh secara simultan rasio kemandirian, rasio efektivitas, dan rasio efisiensi terhadap Pendapatan Asli Daerah Kabupaten Gorontalo tahun 20142018,untuk mengetahui pengaruh rasio kemandirian terhadap Pendapatan Asli Daerah Kabupaten

Gorontalo 2014-2018, Untuk

Mengetahui pengaruh Rasio efektivitas terhadap Pendapatan Asli Daerah Kabupaten Gorontalo 2014- 2018, untuk mengetahui analisis rasio efisiensi terhadap Pendapatan Asli Daerah Kabupaten Gorontalo 2014- 2018.

\section{METODE PENELITIAN}

Jenis penelitian ini merupakan penelitian deskriptif kuantitatif yaitu melakukan perhitungan-perhitungan terhadap data keuangan yang diperoleh untuk memecahkan masalah yang ada sesuai dengan tujuan penelitian. Penelitian ini dimaksudkan untuk mengetahui pengaruh rasio kemandirian, rasio efektivitas dan rasio efisiensi terhadap pendapatan asli daerah Kabupaten Gorontalo.
Dalam penelitian ini menggunakan analisis regresi linier berganda adalah analisis untuk mengetahui pengaruh atau hubungan secara linier antara 2 atau lebih variable independen terhadap 1 variabel dependen, dan untuk memprediksi atau meramalkan suatu nilai variable dependen berdasarkan variable independen (Priyatno, 2014 : 148). Dalam penelitian ini, persamaan regresi linier yang digunakan adalah sebagai berikut :

$$
Y=a+b 1 X 1+b 2 X 2+b 3 X 3+c
$$

Keterangan :

$\mathrm{Y}=$ Pendapatan Asli Daerah

$A=$ Konstanta b1,b2,b3,b4 = Koefisien

Regresi X1 = Rasio Kemandirian

$\mathrm{X} 2=$ Rasio Efektivitas PAD

$\mathrm{X} 3=$ Rasio Efisiensi

C $=$ Eror.

\section{HASIL DAN PEMBAHASAN}

Data yang digunakan dalam penelitian ini adalah Laporan Realisasi Anggaran Pendapatan dan Belanja Daerah Kabupaten Gorontalo yaitu pada tahun 2016-2018. Adapun variable dalam penelitian ini adalah variabel bebas (X1) rasio kemandirian, (X2) rasio efektivitas, (X3) rasio efisiensi dan variabel terikat $(\mathrm{Y})$ pendapatan asli daerah.

1. Pengaruh Rasio Kemandirian, Rasio Efektifitas, dan Rasio Efisiensi Terhadap Pendapatan Asli Daerah Kabupaten Gorontalo

Menurut Halim (2004:94) pendapatan asli daerah adalah penerimaan yang diperoleh daerah dari sumber-sumber dalam wilayahnya sendiri yang dipungut berdasarkan peraturan daerah sesuai dengan perundang-undangan yang berlaku. Pendapatan asli daerah adalah penerimaan yang diperoleh daerah dari sumber-sumber dalam wilayahnya sendiri yang dipungut 
berdasarkan peraturan daerah sesuai dengan peraturan perundang- undangan yang berlaku. Penggunaan rasio kemandirian, rasio efektivitas, dan rasio efisiensi digunakan untuk mengukur sejauh mana rasio-rasio keuangan ini berpengaruh terhadap pendapatan asli daerah. Hasil pengujian regresi menunjukan bahwa nilai probabilitas yang diperoleh dari pengujian lebih kecil dari $0,05(0,000<0,05)$ dengan demikian secara keseluruhan dapat disimpulkan bahwa rasio kemandirian, rasio efektivitas, dan rasio efisiensi secara bersama-sama berpengaruh terhadap pendapatan asli daerah, sementara untuk nilai koefisien determinasi sebesar 0,792 ini berarti bahwa sebesar $79,2 \%$ besarnya pendapatan asli daerah dapat dijelaskan oleh rasio kemandirian, rasio efektivitas, dan rasio efisiensi adapun pengaruh dari variabel lainnya sebesar 20,8\% yang dapat dipengaruhi oleh variabel lainnya. Hasil penelitian ini sesuai dengan penelitian yang dilakukan oleh Yulianah (2017) yang menyatakan bahwa rasio kemandirian, rasio efektvitas, dan rasio efisiensi berpengaruh terhadap pertumbuhan ekonomi Provinsi Jawa Barat Tahun Anggaran 2010-2014.

\section{Pengaruh Rasio Kemandirian Terhadap Pendapatan Asli Daerah Kabupaten Gorontalo}

Salah tujuan utama dari desentralisasi fiskal adalah terciptanya kemandirian daerah. Pemerintah daerah diharapkan mampu menggali sumber-sumber keuangan lokal agar dapat meningkatkan PAD, jika PAD meningkat maka dana yang dimiliki oleh pemerintah daerah akan lebih tinggi. Keberhasilan kemampuan keuangan daerah dalam melaksanakan otonomi daerah salah satunya dilihat dari kemandirian keuangan daerah. Menurut Halim (2012) menyatakan bahwake mandirian menggambarkan ketergantungan daerah terhadap sumber dana eksternal. Semakin tinggi rasio kemandirian maka mengandung arti bahwa tingkat ketergantungan daerah terhadap bantuan pihak eksternal semakin rendah. Rasio kemandirian juga menggambarkan tingkat partisipasi masyarakat dalam pembangunan daerah, semakin tinggi rasio kemandirian maka semakin tinggi partisipasi masyarakat dalam membayar pajak dan retribusi daerah yang merupakan komponen utama dari pendapatan asli daerah. Berikut ini merupakan pola hubungan pemerintah daerah dengan pemerintah pusat:

a. Pola hubungan instruktif yaitu peran pemerintah pusat lebih dominan dari pada kemandirian suatu daerah

b. Pola hubungan konsultatif dimana campur tangan pemerintah pusat sudah mulai berkurang

c. Pola hubungan partisipatif peran dari pemerintah pusat semakin berkurang

d. Pola delegatif dimana campur tangan dari pemerintah pusat sudah tidak ada karena daerah telah mampu dan mandiri dalam melaksanakan urusan otonomi daerah.

Hasil dari pengujian regresi menunjukan bahwa nilai signifikansi rasio kemandirian adalah 0,000 lebih kecil dari nilai probabilitas $0,05 \quad(0,000<0,05)$ sehingga dapat disimpulkan bahwa rasio kemandirian berpengaruh positif dan signifikan terhadap pendapatan asli daerah. Hasil dari koefisien regresi menunjukan bahwa rasio kemandirian mempunyai hubungan yang searah dengan pendapatan asli daerah, dengan kata lain bahwa ketika rasio kemandirian semakin besar atau mengalami peningkatan maka pendapatan asli daerah juga akan mengalami peningkatan, dilihat dari hasil koefisien regresi jika rasio kemandirian mengalami kenaikan sebesar $1 \%$ maka pendapatan asli 
daerah mengalami kenaikan sebesar $20,729 \%$. Hasil penelitian ini sejalan dengan Yulianah (2017) yang menjelaskan tentang semakin tinggi rasio kemandirian maka pendapatan asli daerah akan mengalami peningkatan pula ini dikarenakan rasio kemandirian ditunjukan oleh besar kecilnya pendapatan daerah yang dibandingkan dengan pendapatan asli daerah dan pendapatan yang berasal dari pemerintah.

3. Pengaruh Rasio Efektivitas Terhadap Pendapatan Asli Daerah Kabupaten Gorontalo

Rasio efektivitas menggambarkan kemampuan pemerintah dalam merealisasikan pendapatan asli daerah yang direncanakan dibandingkan dengan target yang ditetapkan berdasarkan potensi riil daerah. Menurut Halim (2012) menyatakan bahwa rasio efektivitas menggambarkan kemampuan pemerintah daerah dalam merealisasikan pendapatan yang direncanakan, kemudian dibandingkan dengan target yang ditetapkan berdasarkan potensi riil daerah. Pemerintah daerah dikatakan mampu menjalankan tugasnya dengan baik, apabila rasio efektivitas yang dicapai sebesar $100 \%$ atau semakin tinggi rasio efektivitasnya berarti kemampuan daerah dalam memaksimalkan potensi pendapatan yang semakin baik jika rasio efektivitas kurang dari $100 \%$ maka rasio efetivitas dikategorikan tidak efektif. Hasil dari pengujian regresi menunjukan bahwa nilai signifikansi 0,002 lebih kecil dari nilai probabilitas $0,05(0,002<0,05)$ sehingga rasio efektivitas berpengaruh positif dan signifikan terhadap pendapatan asli daerah Kabupaten Gorontalo. Hasil dari koefisien regresi menunjukan bahwa rasio efektivitas mempunyai hubungan yang searah dengan pendapatan asli daerah, dengan kata lain bahwa ketika rasio efektivitas semakin besar atau mengalami peningkatan maka pendapatan asli daerah juga akan mengalami peningkatan, dilihat dari hasil koefisien regresi jika rasio efektivitas mengalami kenaikan sebesar $1 \%$ maka pendapatan asli daerah mengalami kenaikan sebesar $14,509 \%$. Hasil penelitian ini sejalan dengan Yulianah (2017) yang menjelaskan bahwa rasio efektivitas berpengaruh positif dan signifikan ini dikarenakan jika rasio efektivitas mengalami peningkatan berarti kemampuan daerah dalam memaksimalkan potensi daerah untuk meningkatkan pendapatan asli daerah semakin baik.

\section{Pengaruh Rasio Efisiensi Terhadap Pendapatan Asli Daerah Kabupaten Gorontalo}

Rasio efisiensi menggambarkan perbandingan antara besarnya biaya yang dikeluarkan untuk memperoleh pendapatan dengan realisasi pendapatan yang diterima. Rasio efisiensi menggambarkan tingkat kemampuan pemerintah dalam mengefisiensikan biaya yang dikeluarkan oleh pemerintah. Menurut Mardiasmo (2013 : 112) yang menyatakan bahwa bila semakin kecil rasio efisiensi berarti kinerja pemerintah daerah semakin baik, ini sejalan dengan hasil pengujian regresi menunjukan bahwa nilai signifikansi rasio efisiensi 0,006 lebih kecil dari $0,05(0,006<0,05)$ ini dapat dikatakan bahwa rasio efisiensi bersifat signifikan namun berpengaruh negatif. Hasil dari koefisien regresi menunjukan bahwa rasio efisiensi mempunyai hubungan yang tidak searah dengan pendapatan asli daerah, dengan kata lain bahwa ketika rasio efisiensi semakin besar atau mengalami peningkatan maka pendapatan asli daerah akan mengalami penurunan, dilihat dari hasil koefisien regresi jika rasio efisiensi mengalami kenaikan sebesar $1 \%$ maka pendapatan asli daerah mengalami 
penurunan sebesar $3,382 \%$ jadi ketika rasio efisiensi semakin besar atau melebihi $100 \%$ maka akan berdampak negatif terhadap pendapatan asli daerah. Hasil penelitian ini sejalan dengan Yulianah (2017) yang menjelaskan bahwa pemerintah daerah harus mampu meminimalisir pengeluaran yang dialokasikan untuk belanja daerah karena meskipun pemerintah berhasil merealisasikan penerimaan pendapatannya sesuai target yang ditetapkan tetapi ternyata biaya yang dikeluarkan untuk memperoleh pendapatan lebih besar dari capaian pendapatannya maka itu akan menjadi siasia.

\section{KESIMPULAN}

1 Rasio kemandirian, rasio efektivitas, dan rasio efeisiensi berpengaruh signifikan terhadap pendapatan asli daerah Kabupaten Gorontalo.

2 Rasio kemandirian berpengaruh positif terhadap pendapatan asli daerah Kabupaten Gorontalo karena ketika rasio kemandirian mengalami peningkatan maka pendapatan asli daerah Kabupaten Gorontalo akan mengalami peningkatan pula. Rasio efektivitas berpengaruh positif terhadap pendapatan asli daerah Kabupaten Gorontalo karena jika rasio efektivitas semakin besar maka pendapatan asli daerah Kabupaten Gorontalo akan mengalami peningkatan.

3 Rasio efisiensi menunjukan hasil yang signifikan terhadap pendapatan asli daerah tetapi berpengaruh negatif dilihat dari nilai koefisien regresi variabel rasio

efisiensi yang menunjukan bahwa semakin besar presentasi rasio efisiensi maka pendapatan asli daerah akan mengalami penurunan.

\section{SARAN}

Berdasarkan hasil penelitian dan kesimpulan yang telah diuraikan di atas, maka saran penelitian ini sebagai berikut :

1. Pemerintah Kabupaten Gorontalo perlu lebih memaksimalkan pengelolaan potensi pendapatan asli daerah dengan cara mengoptimalkan penerimaan dari potensi pendapatannya yang telah ada serta upaya untuk PAD bisa dilakukan dengan melaksnakan secara optimal pemungutan pajak (pajak hotel, pajak restoran dan rumah makan, pajak hiburan, pajak reklame, pajak penerangan jalan, pajak bahan galian golongan c dan pajak pemanfaatan air bawah tanah dan pemukiman) dan retribusi daerah (retribusi jasa umum, retribusi jasa usaha, retribusi jasa tertentu) sehingga dapat kemandirian daerah maka tingkat ketergantungan terhadap pusat makin berkurang.

2. Pemerintah Kabupaten Gorontalo agar mampu merealisasikan pendapatan asli daerah yang telah dianggarkan dengan cara mensosialisasikan pentingnya membayar pajak atau melakukan pemeriksaan di setiap kecamatan yang kiranya belum terdaftar atau bahkan belum memenuhi tanggung jawabnnya sebagai wajib pajak.

Untuk peneliti selanjutnya karena hasil penelitian ini menemukan ada 20,8\% variabel yang tidak dijelaskan dalam penelitian ini maka perlu diteliti adanya kemungkinan variabel lain yang berpengaruh terhadap pendapatan asli daerah dan peneliti selanjutnya agar melakukan evaluasi terhadap otonomi daerah Kabupaten Gorontalo. 


\section{REFERENSI}

Halim, Abdul. (2004). Bunga Rampai Manajemen Keuangan Daerah Edisi Revisi. Yogyakarta : UPP AMP YKPN

Halim, Abdul. (2012). Akuntansi Keuangan Daerah. Jakarta : Salemba Empat

Mardiasmo. (2013). Perpajakan Edisi Revisi. Yogyakarta : Andi, 112

Priyatno, Duwi. (2014). Spss 22 Pengolah Data Terpraktis. Andi : Yogyakarta

Peraturan Pemerintah Nomor 58 Tahun 2005 Tentang Pengelolaan Keuangan Daerah

Undang Undang Republik Indonesia Nomor 23 Tahun 2014 Tentang Pemerintah Daerah

Yulianah, Siti. (2018). Pengaruh Efektivitas Pendapatan Asli Daerah, Efisiensi Keuangan Daerah, dan Kemandirian Keuangan Daerah Terhadap Pertumbuhan Ekonomi Provinsi Jawa Barat Tahun 2010-2014 